\title{
The Bressa prize
}

\section{G. Carle}

To cite this article: G. Carle (1897) The Bressa prize, Philosophical Magazine Series 5, 43:261, 152-152, DOI: $10.1080 / 14786449708620977$

To link to this article: http://dx.doi.org/10.1080/14786449708620977

曲 Published online: 08 May 2009.

Submit your article to this journal

Џ Article views: 2

Q View related articles $₫$ 
bonic acid it increases about in proportion to the partial pressure of the detonating gas.

4. If, on the contrary, detonating gas is mixed with oxygen, the length of the shortest spark producing ignition at first decreases and then increases. The minimum is attained with a mixture of equal volumes of hydrogen and oxygen.

The investigation is being continued.-Wiener Berichte, Dec. 17, 1896.

\section{THE BRESSA PRIZE.}

The Royal Academy of Sciences of Turin, in accordance with the last will and testament of Dr. Cesare Alessandro Bressa, and in conformity with the Programme published December 7th, 1876, announces that the term for competition for scientific works and discoveries made in the four previous years $1893-96$, to which only Italian Authors and Inventors were entilled, was closed on December 31st, 1896.

The Academy now gives notice that from the lst of January 1895 the new term for competition for the eleventh Bressa Prize has begun, to which, according to the testator's will, scientific men and inventors of all nations will be admitted. A prize shall therefore be awarded to the scientific Author or Inventor, whatever his nationality, who during the years 1895-98, "according to the judgment of the Royal Academy of Sciences of Turin, shall have made the most important and useful discovery, or published the most valuable work on physical and experimental Science, Natural History, Mathematics, Chemistry, Physiology and Pathology, as well as Geology, History, Geography and Statistics."

The term will be closed at the end of December 1898.

The sum fixed for the prize, deducting income tax, will be 9600 (nine thousand and six hundred) francs.

Competitions must be sent in within the above-stated time, accompanied by a letter to the President of the Academy. Works must be in print; manuscripts are discarded. Unsuccessful competitive works are not returned.

None of the national members, resident or non-resident, of the Turin Academy can obtain the prize.

The Academy awards the prize to the most worthy scientific person, even if not entering into competition.

The President of the Academy, G. Carle.

Turin, January 1,1897 . 